JURNAL AL BAYAN: JURNAL JURUSAN PENDIDIKAN BAHASA ARAB

\title{
The Implementation of Mimicry Memorization Method for Novice Students in Learning Arabic Mufradat
}

\author{
Nor Afifah $^{1}$, Sunarto ${ }^{2}$, Moh. Fery Fauzi $^{3}$, Irma Anindiati ${ }^{4}$, Talqis Nurdianto ${ }^{5}$ \\ ${ }^{1}$ Arabic Education Study Program Universitas Muhammadiyah Malang, Indonesia \\ 2 Arabic Education Study Program Universitas Muhammadiyah Malang, Indonesia \\ ${ }^{3}$ Arabic Education Study Program Universitas Muhammadiyah Malang, Indonesia \\ ${ }^{4}$ Arabic Education Study Program Universitas Islam Negeri Maulana Malik Ibrahim Malang, Indonesia \\ ${ }^{5}$ Arabic Education Study Program Universiti Sains Islam Malaysia, Malaysia
}

Article History:

Received : February 22, 2020

Revised : March 20, 2020

Accepted : April 26, 2020

Published : December 01, 2020

Keywords:

Evaluation; Learning; Repetition;

Thariqah Muhakah wa Mudhaharah

*Correspondence Address:

mohferyfauzi@umm.ac.id

\begin{abstract}
Students of junior schools that have never studied Arabic language in elementary schools get more difficulties than the students that have studied it before. They are called novice students and must learn basic things of a new language such as mufradat because they must master, memorize, understand, and use it in order to have a good grip of mufradat, translate it, and able to use it in correct phrases and sentences. This research aimed to investigate the effectiveness of using mimicry memorization method for learning mufradat in Junior High School of Muhammadiyah and to investigate the extent which students improve memorization skills after using mimicry memorization method. The research was a quantitative method with a type of experimental research techniques. The data research was collected from observation, documentation, and oral tests techniques. The population of the study included 7 th grade students of Junior High School Muhammadiyah $8 \mathrm{Batu}$ and the samples were 7C students as experimental class and 7D students as control class. The results of research contributed that there was an increase 0.825 (large level) point in students' memorizing ability after using mimicry memorization method. This method was effective to use for novice students in learning mufradat. A language teacher needs to consider this method for novice students. The study provides further support for the use mimicry memorization method for novice students in mastering new vocabularies.
\end{abstract}

\section{Introduction}

Learning mufradat is very important for novice foreign learners because mufradat is the initial stage for learning Arabic and urgent for the four language skills namely listening, speaking, reading and writing. ${ }^{1}$ In the fact, there are many students who get

${ }^{1}$ Abdurochman Abdurochman, 'Strategi Pembelajaran Kosakata Bahasa Arab Bagi Non Arab', An Nabighoh: Jurnal Pendidikan Dan Pembelajaran Bahasa Arab, 19.1 (2017): 63-83, https://doi.org/10.32332/an-nabighoh.v19i1.758. 
difficulty in mastering mufradat due to various factors and students' backgrounds as happened in SMP Muhammadiyah 8 Batu. There are many students in VII grade of junior high school get difficulty in pronouncing mufradat and Arabic letters that are not Indonesian $^{2}$ and memorizing mufradat in the process of learning in junior high school of Muhammadiyah 8 Batu. This is one of the problems which makes them difficult to learn Arabic. To ease the students in memorizing mufradat, teacher needs appropriate method that can increase the mastery of mufradat, whereas the mufradat is the important thing that have to be mastered to learn Arabic $^{3}$ especially for novice students. Many people still assumed that learning Arabic is difficult ${ }^{4}$ because as foreign language, it is often a compulsory school subject. ${ }^{5}$ It has never been easier to design and develop a vocabulary teaching and testing. ${ }^{6}$

The main practical problems that confronts us are the mastery, memorizing, understanding, and using vocabularies in phrases and sentences among the students of $7^{\text {th }}$ grade in junior high school of Muhammadiyah 8 Batu. These problems have attracted more attention in the field of Arabic mufradat. Unfortunately, this approach results in problems related to input and background of students that they studied in elementary schools. This is a basic chicken-and-egg problem because different input and background of students caused difference in learning outcomes of Arabic lesson. This leads to myriad problems that majority students graduated from Islamic elementary schools have studied Arabic lesson in their schools because Arabic lesson is one of compulsary lessons according to Indonesia's instructional curriculum year 2013 called K13. The students that graduated from public elementary schools, generally, have not studied Arabic lessons. These problems have received substantial interest. The data of students' schools background is explained in table 1 .

\footnotetext{
${ }^{2}$ Risna Rianti Sari, 'The Use of Keyword and Imagery Mnemonic for Vocabularies Learning for AFL Students', Izdihar: Journal of Arabic Language Teaching, Linguistics, and Literature, 1.2 (2018): 129-36, https://doi.org/10.22219/izdihar.v1i2.7294.

${ }^{3}$ Moh. Fery Fauzi, 'Mawad Al-Mufradat al-'Arabiyyah Fi al-Manahij al-Dirasiyyah 'ala Asasy alKafa'ah Bi Indunisia: Dirasah Tahliliyyah Taqwimiyyah 'an Tathbiq Mawad al-Mufradat Fi al-Muqarrarat al-Madrasiyyah', Lisaniyat: Jurnal Studi Bahasa Arab 8, No.1 (2017): 16.

${ }^{4}$ Arif Humaini, 'Experimental Research: The Effectiveness of Card Game Learning Media in Learning Shorof', Jurnal Al Bayan: Jurnal Jurusan Pendidikan Bahasa Arab, 10.2 (2018): 295-307, https://doi.org/10.24042/albayan.v10i2.2996.

${ }^{5}$ Marije Michel and others, 'The Role of Working Memory in Young Second Language Learners' Written Performances', Journal of Second Language Writing, 45 (2019): 31-45, https://doi.org/10.1016/j.jslw.2019.03.002.
} 
Table 1. Students' Educational Background and Input From Elementary Schools of $7^{\text {th }}$ Grades of SMP Muhammadiyah 8 Batu

\begin{tabular}{ccccc}
\hline No. & Class & Quantity of Students & \multicolumn{2}{c}{ Graduation } \\
\cline { 3 - 5 } & & & SD & MI \\
\hline 1 & A & 32 & 32 & - \\
\hline 2 & B & 22 & 21 & 1 \\
\hline 3 & C & 31 & 28 & 3 \\
\hline 4 & D & 32 & 29 & 3 \\
\hline 5 & E & 31 & 29 & 6 \\
\hline 6 & F & 23 & 17 & $15(8,77 \%)$ \\
\hline
\end{tabular}

Table 1 above is data of Students' Schools Background and input From Elementary Schools. It is known that the educational background of students of SMP Muhammadiyah 8 Batu in $7^{\text {th }}$ is various. Total of students are 171 students. 156 students graduated from public elementary schools called Sekolah Dasar (SD) and 15 students graduated from Islamic elementary school called Madrasah Ibtidaiyah (MI). Students that graduated from Islamic elementary have studied Arabic lesson while students that graduated from public elementary schools have not studied Arabic lesson. It means that 156 students $(91,22 \%)$ have never studied Arabic lesson in schools and only 15 students $(8.77 \%)$ have studied it. This problem underlies the students of SMP Muhammadiyah 8 Batu difficult in learning Arabic especially in mastery, memorizing, understanding, and using vocabularies in phrases and sentences because among the majority of students learn new language for them that they can not write and read vocabularies. In order to rectify the problems, it needs special treatment with basic learning of Arabic language such as mufradat, pronunciation, and memorizing. It also needs special method and model of learning those basic skills of Arabic language.

Learning Arabic language in Indonesia mostly uses a traditional method ${ }^{7}$, that is oral method. This learning method is conducted by presenting material through oral explanation by a teacher to his students. In addition, based on observation made by researchers, mufradat learning in SMP Muhammadiyah 8 Batu also does not get specific time for mastery of mufradat. Teachers tend to ignore and directly teach the main

${ }^{6}$ Norbert Schmitt, Paul Nation, and Benjamin Kremmel, 'Moving the Field of Vocabulary Assessment Forward: The Need for More Rigorous Test Development and Validation', Language Teaching, 2019: 1-12, https://doi.org/10.1017/S0261444819000326.

${ }^{7}$ Moh Fery Fauzi and Irma Anindiati, 'Tathwir Al-Lughaz al-Raqmy Li Madah al-Tathbiq AlSharfy 1 'ala al-Hatif al-Mahmul Ka al-Tadribat al-Idhafiyyah Kharij al-Fashl al-Dirasy', Buletin Al-Turas, 25.1 (2019): 129-139, https://doi.org/10.15408/bat.v25i1.11506. 
material in the book. Based on interview with Arabic language teachers, mufradat is considered as something that can be mastered by students without any time and special learning. Teachers forget that novice students need special treatment.

It is a complex problem based on the abovementioned phenomenon and to simplify it requires appropriate method in teaching and learning process. There are many methods that teacher can use to achieve learning objectives because a teacher has a very important task in the process of learning activities. One of methods that can be used by teacher in order to make the activity of learning and teaching better is mimicry memorization method especially for novice students. Based on the abovementioned problems, a teacher is expected to be able to analyze the problems that occur in students and the source of problem. Teachers are also required to be more professional in choosing methods and managing the teaching and learning process. However, there are still many teachers who use the lecture method in teaching Arabic specifically teaching mufradat that cause no increase in students' understanding of learning Arabic.

With this phenomenon, the researchers used mimicry memorization method as a method in learning mufradat for novice students. Mimicry means repetition and memorization means the process of committing or learning something to memory because the field of language teaching and learning is in dire need of replications of vocabulary. ${ }^{8}$ This method is often called with information-drill method, because the exercises are done not only for instructor but also for an informant native speaker (native informant). The kind activity in this method is demonstration and exercise/drilling grammar/sentence structure ${ }^{9}$, speech practice, and practice using vocabulary, by imitating native speaker. In drilling, native informant acts as drilling master, he says a few sentences and the students imitate him several times until they memorize in their memory. ${ }^{10}$ The phenomenon whereby successful retrievals from memory contribute to greater long-term retention than unsuccessful retrievals. ${ }^{11}$

\footnotetext{
${ }^{8}$ Aydin Yücesan Durgunoğlu and Martha Bigelow, 'Classroom-Based L2 Vocabulary Learning and Comprehension: Replications of Lesaux, Kieffer, Faller \& Kelley (2010)', Language Teaching, 50.3 (2017): 384-394, https://doi.org/10.1017/S0261444816000239.

${ }^{9}$ Ulin Nuha, Metodologi Super Efektif Pembelajaran Bahasa Arab (Yogyakarta: Diva Press, 2016), 216.

${ }^{10}$ Ahmad Muhtadi Anshor, Pengajaran Bahasa Arab Media Dan Metode-Metodenya (Yogyakarta: Sukses Offset, 2009), 75-76.

11 Tatsuya Nakata and Stuart Webb, 'Does Studying Vocabulary in Smaller Sets Iincrease Learning?: The Effects of Part and Whole Learning on Second Language Vocabulary Acquisition', Studies in Second Language Acquisition, 38.3 (2016): 523-52, https://doi.org/10.1017/S0272263115000236.
} 
In term of Arabic, this method can be called with Thariqah al-Muhakah wa alMudhaharah. So, this method is a learning method which more emphasis to imitate and memorize or a process to remember everything with the strength of memory. ${ }^{12}$ In mimicry memorization method, students impersonate what they heard from their teacher about mufradat and also the sentence than they impersonate it repeatedly. The purpose of this repetition is student able to pronounce mufradat and sentence fluently and correctly because repetition training is a common method of vocabulary instruction in which learners repeat. ${ }^{13}$ Besides that, they are easier to remember it without they realize.

Based on the researchers' exploration, there are several previous studies relating to this research. Sholeh ${ }^{14}$ has conducted a research entitled "Penerapan Metode Mimicry Memorization dalam Pembelajaran Al-Kalam Bagi siswa kelas XI Madrasah Aliyah Darul Qur'an Gunung Kidul Tahun Ajaran 2014/2015 Academic Year". This study aimed to determine the implementation of mimicry memorization method in learning Kalam and the level of effectiveness for XI MA Darul Qur'an Wonosari Gunungkidul students in academic year 2014/2015. Other studies were research of Zahera ${ }^{15}$ in 2012. This study aimed to describe the increase of students' motivation in the subjects of Tahfizul Qur'an with mimicry memorization method for Short Surahs Material for $3^{\text {rd }}$ grade students of Elementary School 006 Limau Manis Kampar Regency.

Other relevant studies were conducted by ${ }^{~} \operatorname{Ain}^{16}$ in 2016 with the aim to describe qualitatively the implementation of mimicry memorization method in learning Mufradat at MTs. Ash-Syafi'iyyah Jatibarang Brebes Regency. Ghofur et al ${ }^{17}$ conducted research on the effect of communicative language teaching and audio-lingual method as another name of mimicry memorization on English speaking skill across different learning styles.

${ }^{12}$ Bisri Mustafa and Abdul Hamid, Metode Dan Strategi Pembelajaran Bahasa Arab (Malang: UIN Malang Press, 2012), 63.

${ }^{13}$ Caitlin A Rice and Natasha Tokowicz, 'A Review of Laboratory Studies of Adult Second Language Vocabulary Training', Studies in Second Language Acquisition (2019): 1-32, https://doi.org/10.1017/S0272263119000500.

${ }^{14}$ Ismail Sholeh, 'Penerapan Metode Mimicry Memorization Dalam Pembelajaran Al-Kalam Bagi Siswa Kelas XI Madrasah Aliyah Darul Qur'an Gunung Kidul Tahun Ajaran 2014/2015' (UIN Sunan Kalijaga, 2014), 1.

${ }^{15}$ Rifka Zahera, 'Meningkatkan Motivasi Belajar Siswa Melalui Metode Mim Mem Mata Pelajaran Tahfizul Qur'an Materi Surat-Surat Pendek Kelas III Sekolah Dasar Negeri 006 Limau Manis Kecamatan Kampar Kabupaten Kampar’ (UIN Sultan Syarif Kasim Riau, 2012), 1.

${ }^{16}$ Akhlihatul 'Ain, 'Penerapan Metode Mimicry Memorization dalam Pembelajaran Mufradat di MTs Asy-Syafi'iyyah Jatibarang Kabupaten Brebes’ (IAIN Purwakerto, 2016), 1.

${ }^{17}$ Abd Ghofur et al., 'The Effect of Communicative Language Teaching and Audio-Lingual Method on English Speaking Skill Across Different Learning Styles', KnE Social Sciences (2017): 1-7, https://doi.org/10.18502/kss.v1i3.719. 
Herawati ${ }^{18}$ used mimicry memorization or audio-lingual method to improve English speaking skill of students in English Department. Ekawati ${ }^{19}$ conducted research on the effect of TPR and audio-lingual method in teaching English vocabulary. Bidenko and Bespalova $^{20}$ applied mimicry memorization to teach Ukranian as a foreign language. Matamoros-González ${ }^{21}$ compared the grammar-translation, audiolingual, communicative and natural approaches for English language teaching.

Previous studies indicate that the Mimicry memorization method can improve learning outcomes in learning. The difference between previous research and this research is the application of the method of mimicry memorization in Arabic learning related to learning mufradat. The novelty of this research in particular is Mimicry memorization which is applied to mufradat learning. Mimicry memorization method can be applied to all foreign languages, Arabic is no exception. Arabic is one of languages learned in Indonesia. Arabic is taught as a main subject at public schools, Islamic boarding schools, madrasahs and at the university level because Arabic has a very important role especially for Moslems as a language of knowledge, a language of communication $^{22}$, social adaptation ${ }^{23}$, language for many Islamic spiritual knowledges ${ }^{24}$ and books that have traditionally been an essential part $^{25}$ and foundation of learning ${ }^{26}$, such as tafsir, hadith, fiqh, tauhid. The application of mimicry memorization in learning

${ }^{18}$ Netty Herawati, 'Audio-Lingual Method as Method in Improving Speaking Ability of Second Semester of English Department Students of UNRIKA', Jurnal Dimensi, 1.3 (2016): 1, http://dx.doi.org/10.33373/dms.v5i3.

19 Anita Dewi Ekawati, 'The Effect of TPR and Audio-Lingual Method in Teaching Vocabulary Viewed from Students' IQ', Journal of ELT Research: The Academic Journal of Studies in English Language Teaching and Learning (2017): 55-65, https://doi.org/10.22236/JER_Vol2Issue1.

${ }^{20}$ Larysa Bidenko and Ganna Bespalova, 'Implementing Audio-Lingual Method to Teaching Ukrainian as a Foreign Language at the Initial Stage', Advanced Education, 7, (2017): 23-2.

21 Jessenia A Matamoros-González and others, 'English Language Teaching Approaches: A Comparison of the Grammar-Translation, Audiolingual, Communicative, and Natural Approaches', Theory and Practice in Language Studies, 7.11 (2017): 965-73, http://dx.doi.org/10.17507/tpls.0711.04.

${ }^{22}$ Ahmad Mubaligh, 'Relasi Bahasa Dan Ideologi', Lingua: Jurnal Ilmu Bahasa dan Sastra, 5.2 (2011): 112-18, http://dx.doi.org/10.18860/ling.v5i2.622.

${ }^{23}$ Norbert Schmitt and others, 'How Much Vocabulary Is Needed to Use English? Replication of van Zeeland \& Schmitt (2012), Nation (2006) and Cobb (2007)', Language Teaching, 50.2 (2017): 21226, https://doi.org/10.1017/S0261444815000075.

${ }^{24}$ Himatul Istiqomah and Hanik Mahliatussikah, 'Musykilat Al-Tarbiyyah Tuwajihuha al-Thalabah Fi Ta'allum al-Lughah al-Arabiyah Li Ghairi al-Nathiqin Biha', Jurnal Al Bayan: Jurnal Jurusan Pendidikan Bahasa Arab, 11.2 (2019): 254-280, https://doi.org/10.24042/albayan.v11i2.5257.

${ }^{25}$ Lane Fischer and others, 'A Multi-Institutional Study of the Impact of Open Textbook Adoption on the Learning Outcomes of Post-Secondary Students', Journal of Computing in Higher Education, 27.3 (2015): 159-72, https://doi.org/10.1007/s12528-015-9101-x.

${ }^{26}$ Nigel A Caplan, 'Learning through Language: A Response to Polio,"Keeping the Language in Second Language Classes", Journal of Second Language Writing, 46 (2019): 1, https://doi.org/10.1016/j.jslw.2019.100677. 
Arabic especially for memorizing mufradat is expected to be able to develop one's ability in Arabic.

The objectives of this study were partially met by developing and implementing a mimicry memorization method to learn mufradat effectively in Arabic teaching and learning process for novice students. Generally, novice students in Arabic learning for this study have never studied Arabic language so they are disable to read and write Arabic letters. The contributions made here have wide applicability. The key contribution of this work is a method solution to learn Arabic mufradat effectively for novice students because it demonstrated the feasibility and the effectiveness level of using mimicry memorization method for novice students in learning Arabic mufradat.

\section{Method}

This study was conducted in Junior High School of Muhammadiyah 8 Batu during 3 months, from January to March 2019. This study aimed to obtain data about the effectiveness of mimicry memorization method for mufradat learning. It also aimed to determine the significance improvement of students' ability in memorizing Arabic mufradat after using mimicry memorization method. The research method of this study was quantitative method. Generally, sampling techniques was carried out randomly. Data collection were conducted by using research instruments, data analysis were conducted quantitatively or by using statistical data analysis with the aim of testing the hypothesis that had been established. ${ }^{27}$

The research design was experimental research using Nonequivalent Control Group Design which was one of Quasi Experimental Designs. In this design, there were two groups selected with certain considerations. First, it was the number of students who were almost the same and the second, examination scores of students were almost the same. The first group was given treatment ( $\mathrm{X}$ variable) and the other groups did not receive any treatment. The pre-test results were considered if the score of experimental groups was not significantly different. ${ }^{28}$ The students' experimental group were given treatment by using mimicry memorization method in learning. Other groups were not experimented with mimicry memorization method.

\footnotetext{
${ }^{27}$ Sugiono Sugiono, Metode Penelitian Pendidikan (Pendekatan Kuantitatif, Kualitatif, Dan R\&D) (Bandung: Alfabeta, 2015), 14.

${ }^{28}$ Sugiono Sugiono, 116.
} 
Data collection techniques that used in this study were observation, oral tests, and documentation. The data were resulted from the score of pre-test and post-test. Data analysis techniques were conducted by using normality test to find out whether the research data that used was normally distributed or not, by using Shapiro Wilk with a significance score level $<0.05$. If the scores were lower than 0.05 , the data were not normally distributed. If the significance score was $>0.05$, the data was normally distributed. Then, the research data were tested using the T-test (two free samples) to test whether there were differences between the two samples. If the data were assumed normally distributed and the probability was 0.05 , the hypothesis $\left(\mathrm{H}_{0}\right)$ was rejected. If the probability was $>0.05$ then the hypothesis $\left(\mathrm{H}_{0}\right)$ was accepted. The effect size test was conducted to to find out the significance of the effectiveness of mimicry memorization method for student learning outcomes in mufradat learning.

\section{Result and Discussion}

\section{The Effectiveness of Using Mimicry Memorization Method for Mufradat Learning}

After conducting data collection, data needs to be analyzed. Before analyzing data, researchers used normality test to find out whether the data was normal or not by using Shapiro Wilk. If the significance level is $<0.05$, the data is not normally distributed. If the significance level is $>0.05$, the data is normally distributed. Then, the data was tested using t-test (Independent Sample T-Test) to find out whether the method was effective or not for mufradat learning.

\section{Normality Test (Pre-Test)}

Normality Test (Pre-test) was conducted in control group and experimental group. The test aimed to find out whether the data that had been obtained by researchers were normally distributed or not. The test was conducted by using Shapiro Wilk and SPSS 22. For more details, the result of research was displayed in table 2.

Table 2. Normality Test of Pre-test Score

\begin{tabular}{ccccc}
\hline \multirow{2}{*}{ Test } & Group & \multicolumn{3}{c}{ Shapiro-Wilk } \\
\cline { 3 - 5 } & & Statistics & Df & Sig. \\
& & .897 & 28 & .010 \\
\hline Pre-test Results & VII Grade Students of C Class & & & \\
\cline { 2 - 5 } & VII Grade Students of D Class & .893 & 30 & .006
\end{tabular}


According to table 2, the normality test of mufradat pre-test using Shapiro Wilk obtained significance score for VII grade students of C class (experimental class). The score was 0.010. The significance score at mufradat pre-test for VII grade students of D class (control class) was 0.006 . The score of both of classes were higher than 0.05 and it could be interpreted that the experimental class and the control class at the mufradat pretest section were normally distributed.

\section{Normality Test (Post-Test)}

Normality Test (Post-test) was conducted in control class and experimental class. The post-test was conducted to find out whether the data that had been obtained by researchers was normally distributed or not. It was conducted by using Shapiro Wilk and SPSS 22. For more details, the result of normality test for mufradat post-test was displayed in table 3.

Table 3. Normality Test of Post-test Score

\begin{tabular}{lcccc}
\hline \multirow{2}{*}{ Test } & \multirow{2}{*}{ Group } & \multicolumn{3}{c}{ Shapiro-Wilk } \\
\cline { 3 - 5 } & & Statistics & Df & Sig. \\
\hline \multirow{3}{*}{ Post-test Results } & VII Grade Students of C Class & .896 & 28 & .009 \\
\cline { 2 - 5 } & & & & \\
& VII Grade Students of D Class & .893 & 30 & .006 \\
\hline
\end{tabular}

According to table 3, the results of normality test at the post-test using Shapiro Wilk test for VII grade students of C class was .009. The significance score at post-test for VII grade students of class D (control class) was .006. It could be interpreted that the experimental class and the control class was normally distributed because the score was higher than 0.05 .

\section{Conducting T-Test}

After obtaining results that control class and experimental class were normally distributed, then t-test was conducted. T-test was used to determine the effectiveness level of mimicry memorization method by the assistance of SPSS 22 using Independent Sample T-test with significance level of 0.05 . The following was the formulation of hypothesis:

$\mathrm{H}_{0}$ : Mimicry memorization method was not effective for mufradat learning

$\mathrm{H}_{1}$ : Mimicry memorization method was effective for mufradat learning 
The analysis technique in this study used the Independent Sample T-Test with the help of SPSS 22. It is used to test whether there is an average difference between the two free samples assuming the data whether normally distributed with the provisions that if the probability $<0.05$ then the hypothesis $(\mathrm{Ho})$ is rejected, if probability $>0.05$ then the hypothesis (Ho) is accepted.

Table 4. Independent Sample Test

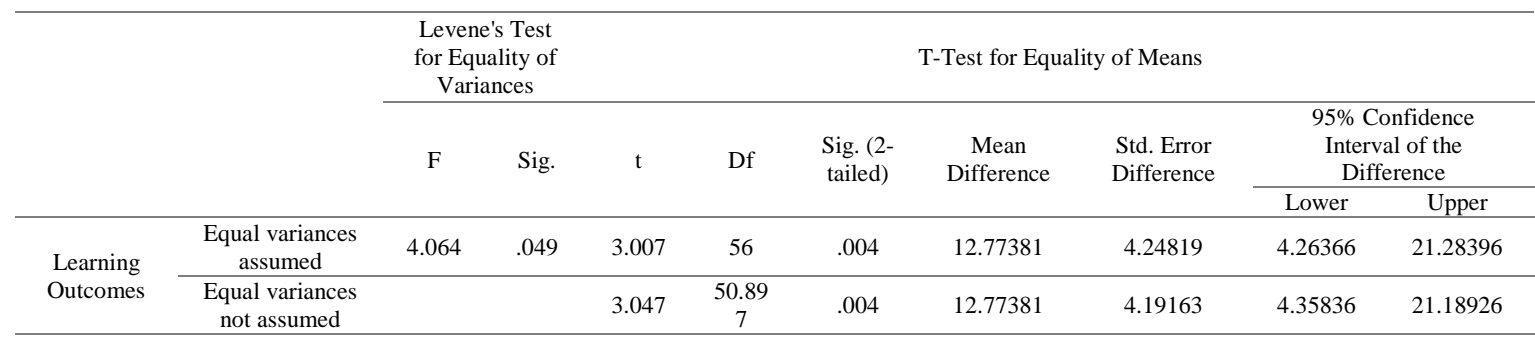

The table 4 explains the learning outcomes of the control class and experimental class after using mimicry memorization method. In Levene's Test for equality of variances, there is no difference in variant with $\mathrm{F}=4.064$ and $\mathrm{p}=0.49$. The data is not homogen and equal because Sig: $p<0.05$. It means that there is difference in variant on learning outcomes between experimental and control class. From table 4, data is taken from data equal variances not assumed because there data is not homogen and equal. The result of t-test for equality of means in table 4 showed that the value of sig. (2-tailed) is 0,04 . The score is less than $0,05(0,04<0,05)$. It means that there is difference learning outcomes between the control class and the experimental class after using mimicry memorization method.

Feng and $\mathrm{Webb}^{29}$ resulted on their research that L2 incidental vocabulary learning occured through reading, listening, and viewing, and the gain was restrained in all modes of input one week after encountering the input. However, no sigificant differences were found between the three modes in the posttest indicating that each mode of input yielded similiar amounts of vocabulary gain and retention. Feng and Webb's result is different from this study of learning Arabic vocabulary with a treatment of mimicry memorization method. This research had significant level of vocabulary acquisition for novice students because the students were treated by repitition and sistematic method. This significance

${ }^{29}$ Yanxue Feng and Stuart Webb, 'Learning Vocabulary Through Reading, Listening, and Viewing: Which Mode of Input Is Most Effective?', Studies in Second Language Acquisition (2019): 1-25, https://doi.org/10.1017/S0272263119000494. 
differs from previous research. This fact can be compromized with the theory cone of learning experience by Edgar Dale. ${ }^{30}$ Experience of verbal receiving, visual receiving, receiving and participating, and doing in learning process will increase learning outcomes and purpose.

\section{Significance Level after Using Mimicry Memorization Method in Mufradat} Learning Effect Size Test

Effect size test was used to find out the effectiveness level of mimicry memorization method toward students' learning outcomes. The students' score by using effect size is shown in table 5 .

Table 5. Effect Size of Students' Score

Statistics

Sd Control

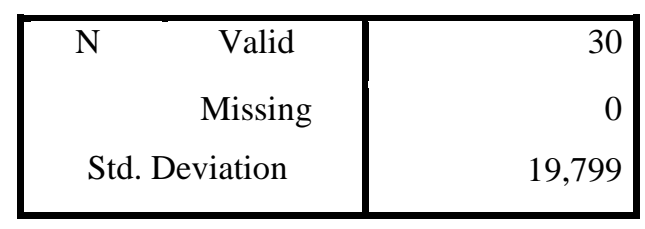

Tabel 5 shows that the standard deviation of students' score was 19,799. The score was rounded to twenty (20). The average score of experimental class was 79,5 and control class was 63. In accordance with the formula that had been determined, it can be counted that $(79,5-63): 20=0,825$ (seventy nine point five minus sixty three then the result is divided by 20 equals zero point eight two five). The score 0,825 is interpreted based on the table of effect size criteria in table 6 in order to know the level of effect of the research on mimicry memorization method toward students in Arabic mufradat learning.

Table 6. Criteria of Effect Size (d)

\begin{tabular}{cc}
\hline Criteria of Effect Size & Category \\
\hline $\mathrm{d}<0,2$ & Small Effect \\
\hline $0,2<\mathrm{d}<0,8$ & Medium Effect \\
\hline $\mathrm{d}>0,8$ & Large Effect
\end{tabular}

${ }^{30}$ Moh Fery Fauzi, Miftahul Fadliah Buhun, and Agus Purwadi, 'The Influence of Teams Games Tournament (TGT) toward Students' Interest in Arabic Language Learning', Izdihar: Journal of Arabic Language Teaching, Linguistics, and Literature, $2.2 \quad$ (2019): 135-148, https://doi.org/10.22219/jiz.v2i2.9986.

273 | Jurnal Al Bayan: Jurnal Jurusan Pendidikan Bahasa Arab, 12 (2): 263-280 (2020) 
Table 6 describes the category and criteria of effect size, the higher the score of Effect Size (ES), the higher effectiveness of mimicry memorization method on mufradat learning. If the range score of effect size criteria is less than 0.2 , the category is small. If the range score of effect size criteria is 0.2 or more and less than 0.8 , the category is average. If the range score of effect size criteria is bigger than 0.8 , the category is large. Based on criteria of effect size in table 5, the results of counting could be concluded that the point of effectiveness of mimicry memoriation method for mufradat learning in Junior High School of Muhammadiyah 8 Batu was 0.825. According to table of effect size criteria, the obtained score was included in the category of large effect.

This research indicated the mimicry memorization method was effective for Arabic mufradat learning as mufaradat is fundamental to comprehending and producing a second language. ${ }^{31}$ This method can be used and designed for training of four language skills and competency or core academic language skills (CALS), ${ }^{32}$ they are listening, speaking, reading, and writing because vocabulary acquisition involves learning words as the by-product of an activity, ${ }^{33}$ tools to develop someone's language skills, ${ }^{34}$ and made from encounters in meaning-focused input relatively small. ${ }^{35}$ There are five-step model of Arabic mufradat learning through mimicry memorization method ${ }^{36}$, they are : 1) encountering a new word, 2) getting a clear visual image of the word, 3) connecting the form and the meaning, 4) consolidating the form-meaning link, and 5) using the learned words.

\footnotetext{
${ }^{31}$ Henriette L Arndt and Robert Woore, 'Vocabulary Learning from Watching YouTube Videos and Reading Blog Posts', Language Learning \& Technology, $22.3 \quad$ (2018): 124-42, https://doi.org/10125/44660.

32 Christopher D Barr, Paola Uccelli, and Emily Phillips Galloway, 'Specifying the Academic Language Skills That Support Text Understanding in The Middle Grades: The Design and Validation of the Core Academic Language Skills Construct and Instrument', Language Learning, 69.4 (2019): 9781021, https://doi.org/10.1111/lang.12365.

${ }^{33}$ Niousha Pavia, Stuart Webb, and Farahnaz Faez, 'Incidental Vocabulary Learning through Listening to Songs', Studies in Second Language Acquisition, 41.4 (2019): 745-68, https://doi.org/10.1017/S0272263119000020.

34 Sholihah Sholihah, 'Penggunaan Media Gambar Dalam Pembelajaran Mufrodat', Tarling: Journal of Language Education, 1.1 (2017): 62-76, https://doi.org/10.24090/tarling.v1i1.1122.

35 Stuart Webb, 'Learning Vocabulary through Meaning-Focused Input: Replication of Elley (1989) and Liu \& Nation (1985)', Language Teaching, 49.1 (2016): 129-40, https://doi.org/10.1017/S0261444815000051.

${ }^{36}$ Ana Pellicer-Sánchez, 'Incidental L2 Vocabulary Acquisition from and While Reading: An EyeTracking Study', Studies in Second Language Acquisition, 38.1 (2016): 97-130, https://doi.org/10.1017/S0272263115000224.
} 
At first glance, the benefits of mimicry memorization method for Arabic mufradat learning seem considerable and can improve students' vocabulary. Learning vocabulary through simultaneous reading and listening such as mimicry memorization method, is more efficient than through reading and listening alone ${ }^{37}$ even though vocabulary size estimates should be interpreted with great caution. ${ }^{38}$ However, there are disadvantages to this method, which requires lengthy teacher planning time. The realities of classroom life suggest that teachers do not have time to prepare the kind of varied and extensively rich lessons necessary ${ }^{39}$ for mimicry memorization method for Arabic mufradat learning.

The implementation of mimicry memorization method for Arabic mufradat learning is suggested to use appropriate strategies and ways for teachers in building students' motivation and mental because language development is a complex mental process. ${ }^{40}$ Sometimes students need to be motivated when they learn Arabic mufradat, because the students of $7^{\text {th }}$ grades in junior school are from different input. Among students graduated from public elementary school and the rests graduated from Islamic elementary school. Students that graduated from public elementary school sometimes did not learn Arabic lesson, in contrary, students that graduated from Islamic elementary school learnt Arabic lesson. Based on the abovementioned process of mimicry memorization method, it is suggested to teachers to provide students opportunities to develop deep understanding of words. This process may spend 30 minutes a day teaching vocabulary. Therefore, teachers need to choose carefully which Arabic mufradat to teach $^{41}$ and to measure vocabulary acquisition. ${ }^{42}$

\footnotetext{
${ }^{37}$ Anna CS Chang, 'Effects of Narrow Reading and Listening on L2 Vocabulary Learning: Multiple Dimensions', Studies in Second Language Acquisition, $41.4 \quad$ (2019): 769-94, https://doi.org/10.1017/S0272263119000032.

38 Eva Puimège and Elke Peters, 'Learners' English Vocabulary Knowledge Prior to Formal Instruction: The Role of Learner-Related and Word-Related Variables', Language Learning, 69.4 (2019): 943-77, https://doi.org/10.1111/lang.12364.

39 Patricia A. Herman and Janice Dole, 'Theory and Practice in Vocabulary Learning and Instruction', The Elementary School Journal, 89.1 (2005): 43-54, https://doi.org/10.1086/461561.

${ }^{40}$ Alexandra Karousou and Theodora Nerantzaki, 'Phonological Memory Training and Its Effect on Second Language Vocabulary $\quad$ Development', $36.1 \quad$ (2020): $1-24$, https://doi.org/10.1177/0267658319898514.

${ }^{41}$ Patricia A. Herman and Janice Dole, 51.
} 


\section{Conclusion}

The basic result of this research are generally consistent with research hypothesis that mimicry memorization method for mufradat learning in Junior High School of Muhammadiyah 8 Batu was effective to use for Arabic mufradat learning. The effectiveness of mimicry memorization method for mufradat learning was on large level and could be used for Arabic mufradat learning. This method was effective to use for novice students in learning mufradat because they get many experiences in mimicry memorization with various strategy. A language teacher needs to consider this method for novice students. Future researchs are necessary to validate the kinds of conclusions that can be drawn from this study such as developing strategy in vocabulary learning. Further research also can be conducted to examine this methode for intermediate and advance students whether this method of mimicry memorization are still hold true for learning Arabic mufradat.

\section{Acknowledgment}

The authors would like to express gratitude to Universitas Muhammadiyah Malang especially Arabic Education Study Program, Islamic Studies Faculty for supporting this research. This research could be done because the atmosphere of academic is very good and support to the academy, lecturers, and students in learning and teaching process.

\section{References}

Abdurochman, Abdurochman, 'Strategi Pembelajaran Kosakata Bahasa Arab Bagi Non Arab', An Nabighoh: Jurnal Pendidikan Dan Pembelajaran Bahasa Arab, 19.1 (2017): 63-83, https://doi.org/10.32332/an-nabighoh.v19i1.758.

Ahmad Muhtadi Anshor, Pengajaran Bahasa Arab Media Dan Metode-Metodenya (Yogyakarta: Sukses Offset, 2009)

Akhlihatul 'Ain, 'Penerapan Metode Mimicry Memorization Dalam Pembelajaran Mufradat Di MTs Asy-Syafi'iyyah Jatibarang Kabupaten Brebes' (IAIN Purwakerto, 2016)

\footnotetext{
42 Norbert Schmitt, 'Understanding Vocabulary Acquisition, Instruction, and Assessment: A

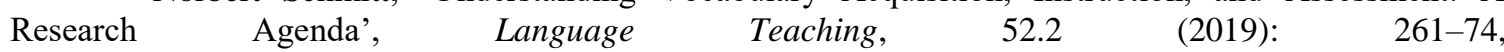
https://doi.org/10.1017/S0261444819000053.
} 
Arif Humaini, 'Experimental Research: The Effectiveness of Card Game Learning Media in Learning Shorof', Jurnal Al Bayan: Jurnal Jurusan Pendidikan Bahasa Arab, 10.2 (2018): 295-307, https://doi.org/10.24042/albayan.v10i2.2996.

Arndt, Henriette L, and Robert Woore, 'Vocabulary Learning from Watching YouTube Videos and Reading Blog Posts', Language Learning \& Technology, 22.3 (2018): 124-42, https://doi.org/10125/44660.

Barr, Christopher D, Paola Uccelli, and Emily Phillips Galloway, 'Specifying the Academic Language Skills That Support Text Understanding in The Middle Grades: The Design and Validation of the Core Academic Language Skills Construct and Instrument', Language Learning, 69.4 (2019): 978-1021, https://doi.org/10.1111/lang.12365.

Bidenko, Larysa, and Ganna Bespalova, 'Implementing Audio-Lingual Method to Teaching Ukrainian as a Foreign Language at the Initial Stage', Advanced Education, 7 (2017): 23-27.

Bisri Mustafa, and Abdul Hamid, Metode Dan Strategi Pembelajaran Bahasa Arab (Malang: UIN Malang Press, 2012)

Caplan, Nigel A, 'Learning through Language: A Response to Polio,"Keeping the Language in Second Language Classes", Journal of Second Language Writing, 46 (2019): 1-2, https://doi.org/10.1016/j.jslw.2019.100677.

Chang, Anna CS, 'Effects of Narrow Reading and Listening on L2 Vocabulary Learning: Multiple Dimensions', Studies in Second Language Acquisition, 41.4 (2019): 769 94, https://doi.org/DOI: https://doi.org/10.1017/S0272263119000032.

Durgunoğlu, Aydin Yücesan, and Martha Bigelow, 'Classroom-Based L2 Vocabulary Learning and Comprehension: Replications of Lesaux, Kieffer, Faller \& Kelley (2010)', Language Teaching, $50.3 \quad$ (2017): $\quad$ 384-94, https://doi.org/10.1017/S0261444816000239.

Ekawati, Anita Dewi, 'The Effect of TPR and Audio-Lingual Method in Teaching Vocabulary Viewed from Students' IQ', Journal of ELT Research: The Academic Journal of Studies in English Language Teaching and Learning, (2017): 55-65, https://doi.org/10.22236/JER_Vol2Issue1.

Fauzi, Moh Fery, and Irma Anindiati, 'Tathwir Al-Lughaz al-Raqmy Li Madah alTathbiq Al-Sharfy 1 'ala al-Hatif al-Mahmul Ka al-Tadribat al-Idhafiyyah Kharij al-Fashl al-Dirasy', Buletin Al-Turas, $25.1 \quad$ (2019): 129-39, https://doi.org/10.15408/bat.v25i1.11506.

Fauzi, Moh Fery, Miftahul Fadliah Buhun, and Agus Purwadi, 'The Influence of Teams Games Tournament (TGT) toward Students' Interest in Arabic Language Learning', Izdihar: Journal of Arabic Language Teaching, Linguistics, and Literature, 2.2 (2019): 135-48, https://doi.org/10.22219/jiz.v2i2.9986. 
Feng, Yanxue, and Stuart Webb, 'Learning Vocabulary Through Reading, Listening, and Viewing: Which Mode of Input Is Most Effective?', Studies in Second Language Acquisition (2019): 1-25, https://doi.org/10.1017/S0272263119000494.

Fischer, Lane, John Hilton, T Jared Robinson, and David A Wiley, 'A Multi-Institutional Study of the Impact of Open Textbook Adoption on the Learning Outcomes of Post-Secondary Students', Journal of Computing in Higher Education, 27.3 (2015): 159-72, https://doi.org/10.1007/s12528-015-9101-X.

Ghofur, Abd, I Nyoman S Degeng, Utami Widiati, and Punaji Setyosari, 'The Effect Of Communicative Language Teaching And Audio-Lingual Method On English Speaking Skill Across Different Learning Styles', KnE Social Sciences (2017): 17, https://doi.org/10.18502/kss.v1i3.719.

Herawati, Netty, 'Audio-Lingual Method as Method in Improving Speaking Ability of Second Semester of English Department Students of UNRIKA', JURNAL DIMENSI, 1.3 (2016): 1-15, http://dx.doi.org/10.33373/dms.v5i3.

Himatul Istiqomah, and Hanik Mahliatussikah, 'Musykilat Al-Tarbiyyah Tuwajihuha alThalabah Fi Ta'allum al-Lughah al-Arabiyah Li Ghairi al-Nathiqin Biha', Jurnal Al Bayan: Jurnal Jurusan Pendidikan Bahasa Arab, 11.2 (2019): 254-80, https://doi.org/10.24042/albayan.v11i2.5257.

Ismail Sholeh, 'Penerapan Metode Mimicry Memorization Dalam Pembelajaran AlKalam Bagi Siswa Kelas XI Madrasah Aliyah Darul Qur'an Gunung Kidul Tahun Ajaran 2014/2015' (UIN Sunan Kalijaga, 2014)

Karousou, Alexandra, and Theodora Nerantzaki, 'Phonological Memory Training and Its Effect on Second Language Vocabulary Development', 36.1 (2020): 1-24, https://doi.org/10.1177/0267658319898514.

Matamoros-González, Jessenia A, María Asunción Rojas, Johanna Pizarro Romero, Sara Vera-Quiñonez, and Sandy T Soto, 'English Language Teaching Approaches: A Comparison of the Grammar-Translation, Audiolingual, Communicative, and Natural Approaches', Theory and Practice in Language Studies, 7.11 (2017): 96573, http://dx.doi.org/10.17507/tpls.0711.04.

Michel, Marije, Judit Kormos, Tineke Brunfaut, and Michael Ratajczak, 'The Role of Working Memory in Young Second Language Learners' Written Performances', Journal of Second Language Writing, 45 (2019): 31-45, https://doi.org/10.1016/j.jslw.2019.03.002.

Moh. Fery Fauzi, 'Mawad Al-Mufradat al-'Arabiyyah Fi al-Manahij al-Dirasiyyah 'ala Asasy al-Kafa'ah Bi Indunisia: Dirasah Tahliliyyah Taqwimiyyah 'an Tathbiq Mawad al-Mufradat Fi al-Muqarrarat al-Madrasiyyah' (UIN Maulana Malik Ibrahim Malang, 2016)

Mubaligh, Ahmad, 'Relasi Bahasa Dan Ideologi', Lingua: Jurnal Ilmu Bahasa Dan Sastra, 5.2 (2011): 112-18, http://dx.doi.org/10.18860/ling.v5i2.622. 
Nakata, Tatsuya, and Stuart Webb, 'Does Studying Vocabulary in Smaller Sets Iincrease Learning?: The Effects of Part and Whole Learning on Second Language Vocabulary Acquisition', Studies in Second Language Acquisition, 38.3 (2016): 523-52, https://doi.org/10.1017/S0272263115000236

Patricia A. Herman, and Janice Dole, 'Theory and Practice in Vocabulary Learning and Instruction', The Elementary School Journal, 89.1 (2005): 43-54, https://doi.org/10.1086/461561.

Pavia, Niousha, Stuart Webb, and Farahnaz Faez, 'Incidental Vocabulary Learning through Listening to Songs', Studies in Second Language Acquisition, 41.4 (2019): 745-68, https://doi.org/10.1017/S0272263119000020.

Pellicer-Sánchez, Ana, 'Incidental L2 Vocabulary Acquisition from and While Reading: An Eye-Tracking Study', Studies in Second Language Acquisition, 38.1 (2016): 97-130, https://doi.org/10.1017/S0272263115000224.

Puimège, Eva, and Elke Peters, 'Learners' English Vocabulary Knowledge Prior to Formal Instruction: The Role of Learner-Related and Word-Related Variables', Language Learning, 69.4 (2019): 943-77, https://doi.org/10.1111/lang.12364.

Rice, Caitlin A, and Natasha Tokowicz, 'A Review of Laboratory Studies of Adult Second Language Vocabulary Training', Studies in Second Language Acquisition (2019): 1-32, https://doi.org/10.1017/S0272263119000500.

Rifka Zahera, 'Meningkatkan Motivasi Belajar Siswa Melalui Metode Mim Mem Mata Pelajaran Tahfizul Qur'an Materi Surat-Surat Pendek Kelas III Sekolah Dasar Negeri 006 Limau Manis Kecamatan Kampar Kabupaten Kampar' (UIN Sultan Syarif Kasim Riau, 2012)

Sari, Risna Rianti, 'The Use of Keyword and Imagery Mnemonic for Vocabularies Learning for AFL Students', Izdihar: Journal of Arabic Language Teaching, Linguistics, and Literature, 1.2 (2018): 129-36, https://doi.org/10.22219/izdihar.v1i2.7294.

Schmitt, Norbert, 'Understanding Vocabulary Acquisition, Instruction, and Assessment: A Research Agenda', Language Teaching, 52.2 (2019): 261-74, https://doi.org/10.1017/S0261444819000053.

Schmitt, Norbert, Tom Cobb, Marlise Horst, and Diane Schmitt, 'How Much Vocabulary Is Needed to Use English? Replication of van Zeeland \& Schmitt (2012), Nation (2006) and Cobb (2007)', Language Teaching, 50.2 (2017): 212-26, https://doi.org/10.1017/S0261444815000075.

Schmitt, Norbert, Paul Nation, and Benjamin Kremmel, 'Moving the Field of Vocabulary Assessment Forward: The Need for More Rigorous Test Development and Validation', Language Teaching (2019): 1-12, https://doi.org/10.1017/S0261444819000326. 
Sholihah Sholihah, 'Penggunaan Media Gambar Dalam Pembelajaran Mufrodat', Tarling: Journal of Language Education, 1.1 (2017): 62-76, https://doi.org/10.24090/tarling.v1i1.1122.

Sugiono Sugiono, Metode Penelitian Pendidikan (Pendekatan Kuantitatif, Kualitatif, Dan R\&D) (Bandung: Alfabeta, 2015)

Ulin Nuha, Metodologi Super Efektif Pembelajaran Bahasa Arab (Yogyakarta: Diva Press, 2016)

Webb, Stuart, 'Learning Vocabulary through Meaning-Focused Input: Replication of Elley (1989) and Liu \& Nation (1985)', Language Teaching, 49.1 (2016): 129-40. https://doi.org/10.1017/S0261444815000051. 